\title{
Do circular economy business models capture intended environmental value propositions?
}

Kaisa Manninen ${ }^{*}, \mathrm{a}, \mathrm{b}$, Sirkka Koskela ${ }^{\mathrm{a}}$, Riina Antikainen ${ }^{\mathrm{a}}$, Nancy Bocken ${ }^{\mathrm{b}, \mathrm{c}}$, Helena Dahlbo ${ }^{\mathrm{a}}$, Anna Aminoff ${ }^{d}$

${ }^{*}$ Corresponding author, Kaisa.Manninen@lut.fi

a Finnish Environment Institute, P.O.Box 140, FI-00251 Helsinki, Finland

${ }^{b}$ Lappeenranta University of Technology, LUT School of Business and Management, P.O.Box 20, FI-53851, Lappeenranta, Finland

${ }^{c}$ Lund University, IIIEE, Tegnérsplatsen 4, 22350 Lund, Sweden

${ }^{d}$ Delft University of Technology, Industrial Design Engineering, Delft, The Netherlands

e HOMIE B.V., Mijnbouwstraat 120, 2618 RX Delft, The Netherlands

${ }^{f}$ VTT Technical Research Centre of Finland, P.O. Box 1000, FI-02044, VTT, Finland

\section{Abstract}

The circular economy (CE) can be a driver for sustainability and CE can be promoted and supported by the creation of new and innovative business models, which embed CE principles into their value propositions throughout the value chains. This study focuses on the environmental value propositions of the CE business models. The term environmental value proposition refers here to an absolute value being a promise of environmental improvement, which a company provides to the environment by its impacts throughout the whole value chain. The aim of this study is to outline a framework for evaluating the environmental value propositions of CE business models. The framework consists of an environmental value propositions table (EVPT) and a step-by-step approach towards an evaluation process. The framework was tested in three CE business model cases. The outlined framework enables a better understanding of circular economy principles, combining them with the environmental value proposition. With the framework, companies can plan and design new CE business models or they can verify intended environmental benefits and analyse their contribution to sustainability. The biggest challenges, when applying the framework, were related to the estimation of environmental benefits gained from the environmental value propositions at the system level. In the future, intensive 
scientific work should concentrate on developing environmental assessment methods specifically for companies developing new CE business models.

\section{Keywords,}

circular economy; business model; environmental impact; value creation; environmental value proposition

\section{Introduction}

The discussion regarding the circular economy (CE) has rapidly increased in the EU in recent years, particularly after the European Commission published Closing the loop - An EU action plan for the Circular Economy in December 2015 (European Commission, 2015). In academic literature, the number of publications on the CE has increased more than tenfold the past decade (Geissdoerfer et al., 2017). A CE is an economy that provides multiple value-creation mechanisms which are decoupled from the consumption of finite resources (Ellen MacArthur Foundation et al., 2015). It is a regenerative system in which resource inputs, waste, emissions, and energy leakage are minimised by slowing, closing, and narrowing material and energy loops, which can be achieved through long-lasting design, maintenance, repair, reuse, remanufacturing, refurbishing, and recycling (Geissdoerfer et al., 2017). A CE aims for a significant increase in the adoption of closing-the-loop of production service patterns within an economic system. In addition to increasing the efficiency of resource use, the aim of a CE is to achieve a better balance and harmony between the economy, the environment and society (Ghisellini et al. 2016). Creating a circular economy requires fundamental changes throughout the value chain and actions are needed at all phases of the value chain and by all stakeholders (EEA, 2016).

A CE can provide many opportunities to create new employment and business growth (European Commission, 2015, Ghisellini et al., 2016, SUN et al., 2015) and one aim of an EU action plan for CE is to reach the 2030 Sustainable Development Goals (European Commission, 2015). In practice, a CE can be promoted and supported by the creation of new 
and innovative business models (Bakker et al., 2014, Bocken et al., 2016b, Lewandowski, 2016, Stahel, 2010) which embed CE principles into their value propositions throughout the value chains (from now on called CE business models). It is not, however straightforward that CE contributes to sustainability and there is substantial uncertainty on the potential environmental impact of new circular business models (Mont, 2002, Mont, 2004, Tukker, 2015). Sustainability aims at benefiting environment, economy and society (triple-bottomline perspective, $T B L$ ), while the CE prioritises the economic systems and gaining environmental benefits while only implicitly including social aspects (Geissdoerfer et al., 2017). Moreover, the positive effect of CE business models such as Product Service Systems (PSS) needs to be explicitly designed into the business model and associated product design, as a positive effect is not guaranteed (Mont, 2002, Mont, 2004, Tukker, 2004, Tukker, 2015). Therefore, it is important to raise the question, whether CE business models truly contribute positively to the environment and how these can be assessed and designed to do so.

In many cases, the verification of environmental benefits of CE business models is not straightforward because of either complex value chains, lack of data, or difficulties in defining a reference system for assessing environmental product improvements. In addition, the existing assessment method are often resource demanding (e.g. ISO 14040:2006). Even when Life Cycle Assessment is applied to a business model context (Lindahl et al., 2014) it suffers from the same shortcomings as LCA's of products, such as making use of average data from databases and making assumptions. However, for decision making about the design of future business models, which is imperative to their positive environmental outcome (Mont, 2002, Mont, 2004, Tukker, 2004, Tukker, 2015) a more streamlined assessment approach would apply (Bocken et al., 2016a).

In this paper, the research gap narrows by bringing out the term environmental value proposition and the importance of its verification in CE business models. The term environmental value proposition refers here to an absolute value being a promise of environmental improvement, which a company provides to the environment by its impacts throughout the whole value chain. As companies provide environmental value propositions, the important questions are: (1) Do "circular businesses" really have a positive influence on the environment when taking into account all activities throughout the value chain? (2) How 
can the environmental impacts and value propositions of circular business models be verified?

The aim of this study is to outline a framework for evaluating the environmental value propositions of CE business models. The evaluation process is meant to be agile and light to not demand too many resources (time/ effort) from the companies involved. This allows companies to design better business models taking into account the notion of the environmental value proposition throughout the business model innovation and design process. This paper introduces a step-by-step approach for the evaluation of environmental value propositions and discusses challenges related to the framework. The development process was based on the literature survey and the case study research for testing the framework in three CE business model cases.

The paper consists of the literature survey of the business models and the circular economy in Section 2. A description of the developed evaluation framework is presented in Section 3. The methodology is described in Section 4 and results are presented in Section 5. The paper concludes with a discussion (Section 6) and conclusions (Section 7).

\section{Literature survey}

\subsection{Business models and business models for sustainability}

In this section, we review the business model literature to gain understanding of CE business models and how these business models support transforming towards circular economy. In addition, tools and methods that could support the assessment of circular business models are reviewed.

The basic term business model refers to a concept that describes the rationale of how an organisation creates, delivers and captures values (Osterwalder and Pigneur, 2010). Boons and Lüdeke-Freund (2013) identify four elements of a generic business model concept:

1) Value proposition: what value is embedded in the product/service offered by the firm; 
2) Supply (or value) chain: how upstream relationships with suppliers are structured and managed;

3) Customer interface: how downstream relationships with customers are structured and managed;

4) Financial model: costs and benefits from 1), 2) and 3) and their distribution across business model stakeholders.

In conventional profit-normative companies, a successful business is usually measured by economic performance (Upward and Jones, 2016). For sustainability thinking, the focus on economic success is too narrow and raises the need for a more holistic view of value that integrates social and environmental goals, to ensure balancing or ideally alignment of all stakeholders (Bocken et al., 2013). Business model that consider a wider group of stakeholders than just customers and shareholders and explicitly consider society and environment as stakeholders is defined sustainable business model (Bocken et al., 2013, Stubbs and Cocklin, 2008) or business models for sustainability (e.g. Schaltegger et al., 2016). The value proposition of business model provides measurable ecological and/or social value in concert with economic value (Boons and Lüdeke-Freund, 2013). Sustainable value cannot be created for customers without creating value to a broader range of stakeholders, because a business is 'carried' by its stakeholder network (Stubbs and Cocklin, 2008). Although a business model is a market-oriented approach, a business that contributes to sustainable development need to create value to the whole range of stakeholder and the natural environment, beyond customers and shareholders (Schaltegger et al., 2016).

\subsection{Circular economy business models}

The CE concept rests on three principles (see also Table 2): preserving and enhancing natural capital, optimising yields from resources in use, and fostering system effectiveness (minimising negative externalities) (Ellen MacArthur Foundation et al., 2015). CE businesses aim to apply these CE principles to their business models and shift from a linear business to more circular ones (Lewandowski, 2016). The European Environment Agency (EEA, 2016) describes the characteristics of CE and classifies them into five main key categories: 1) less input and use of natural resources, 2 ) increased share of renewable and recyclable resources 
and energy, 3) reduced emissions, 4) fewer material losses/residuals, and 5) keeping the value of products, components and materials in the economy (Table 2).

CE business models can be classified in several ways, for example through their environmental strategies including slowing, closing and narrowing resource loops as described by (Bocken et al., 2016b), or six categories, namely short cycle, long cycle, cascading, pure circles, digitisation and produce on demand, as propounded by ten Wolde (2016). However, according to Lewandowski (2016), most of the different business model types can be categorised in the ReSOLVE framework developed by the Ellen MacArthur Foundation. The ReSOLVE framework describes a set of six actions that businesses and governments can take in order to promote transition to a circular economy. The actions are Regenerate, Share, Optimise, Loop, Virtualise and Exchange (Table 1).

Table 1. The ReSOLVE framework (modified from Ellen MacArthur Foundation et al., 2015)

\begin{tabular}{lll}
\hline ReSOLVE business & Description \\
actions & - & \\
\hline Regenerate & - & reclaim, retain and regenerate health of ecosystems \\
& - & return recovered biological resources to the biosphere \\
\hline Share & - & keep product loop speed low \\
& - & maximise utilisation of products by sharing them among users \\
& - & prolong life through maintenance, repair and design for durability \\
\hline Optimise & - increase performance/efficiency of a product \\
& - & remove waste in production and the supply chain \\
\hline Loop & - leverage big data, automation, remote sensing and steering \\
\hline Virtualise & - & keep components and materials in closed loops and prioritise inner loops \\
\hline Exchange & - & replace old materials with advanced non-renewable materials \\
& - & apply new technologies \\
\hline
\end{tabular}

CE is seen to be a driver to sustainability, and sustainable and circular business models are closely related literature streams (Antikainen and Valkokari, 2016). However, CE prioritises the economic systems and environmental benefits while only implicit including social aspects (Geissdoerfer et al., 2017). Nevertheless, lessons can be learned from closely related literature on sustainable business models.

Current literature concentrates on the sustainable or circular economy business model development, leaving a gap for literature about assessment of CE business models. For 
example, Bocken et al. (2016b) developed a framework of strategies to guide designers and business strategists in the move from a linear to a circular economy. Kraaijenhagen et al. (2016) offers a practical 10-step approach for professionals in small, medium-sized and large organisations on how to initiate, lead and execute from pilot to circular businesses. Lewandowski (2016) employs a literature review to identify and classify the circular economy characteristics according to a business model structure, and Patala et al. (2016) offers guidelines on how to construct sustainable value propositions that resonate with customers. In addition, some practical tools for sustainable value creation have been developed, such as the Value Mapping Tool (Bocken et al., 2013), the Sustainable Analysis Tool (Yang, 2014); as well as the Triple Layer Business Model Canvas (Joyce and Paquin, 2016) and The Flourishing Canvas (Upward and Jones, 2016) building on the Osterwalder and Pigneur.

\subsection{Stakeholder and financial perspective of CE business model}

Stakeholders, analogous to sustainable business models (Stubbs and Cocklin, 2008), are important actors in CE business models. These stakeholders at least include the value chain actors and customers (Boons and Lüdeke-Freund, 2013). Circular business models, focusing on slowing, closing and narrowing loops, including strategies such as repair, remanufacturing and recycling (Geissdoerfer et al., 2017) require the development of new value networks that allow products to be returned from customer to manufacturer or other service suppliers to perform activities such as reuse, recycling and repair. Stakeholders relevant to new circular business models can be divided into three groups: stakeholders internal to a company, stakeholders in a value chain and stakeholders in an extended value chain (Tyl et al., 2015). The above mentioned practical tools by Bocken et al. (2013) and Yang et al. (2014) also include a broad stakeholder perspective.

The financial model of a circular business model might look quite different, because businesses pursuing such business models aspire to create new forms of value previously externalised by companies (i.e., creating positive environmental impact). Kraaijenhagen et al. (2016) recommend seeking to increase the 'value pie', rather than 'cutting the same pie 
in smaller pieces', for instance through providing new services (e.g. maintenance and repair) or providing higher priced but better and longer performing products and services.

\subsection{Research contribution based on the literature survey}

Literature survey showed that CE is seen to be one driver for sustainability and several publications about business models for sustainability exist. The studies raise the importance of a measurable value proposition, which provides benefits to environment, in addition to economic and social value. Further, the value is created in addition to customers as well as the broader range of stakeholders, because a business is carried by a stakeholder network (Stubbs and Cocklin, 2008). Therefore, it is important to understand environmental value as an absolute value instead of being only an instrumental value creating economic value. This ideology is used as a basis for developing an evaluation framework.

\section{Outline of the evaluation framework}

The section presents an overall figure of the framework. The evaluation framework for CE business models (Figure 1) was built based on the literature presented in Section 2 . The role of stakeholders is emphasised (Bocken et al., 2013, Stubbs and Cocklin, 2008) as well as the life cycle perspective (Patala et al., 2016, Yang, 2014). A CE business model can comprise both product(s) and service(s). The inner circle represents the CE business model's intended environmental value propositions, which must be defined first by business model developers. For this purpose, the environmental value proposition table (EVPT, Table 2) was developed by the research team (see Section 3.1). The implementation of the value propositions takes place not only in the company but also in the value chain of the product or service. Therefore, all the life cycle stages of a product or service are taken into consideration and they are expressed as beginning of life (BOL), middle of life (MOL) and end of life (EOL) (based on the classification in Yang et al. (2014). The BOL refers to (raw material) extraction and manufacturing stages; the MOL to wholesale, retail, logistics, and customer usage of the product, and the EOL to repair, reuse and remanufacturing stages. The identification of the stakeholders and their role is also included in the framework. The 
evaluation process of the realisation of value propositions consist of five steps, which are explained in more detail in Section 3.2.

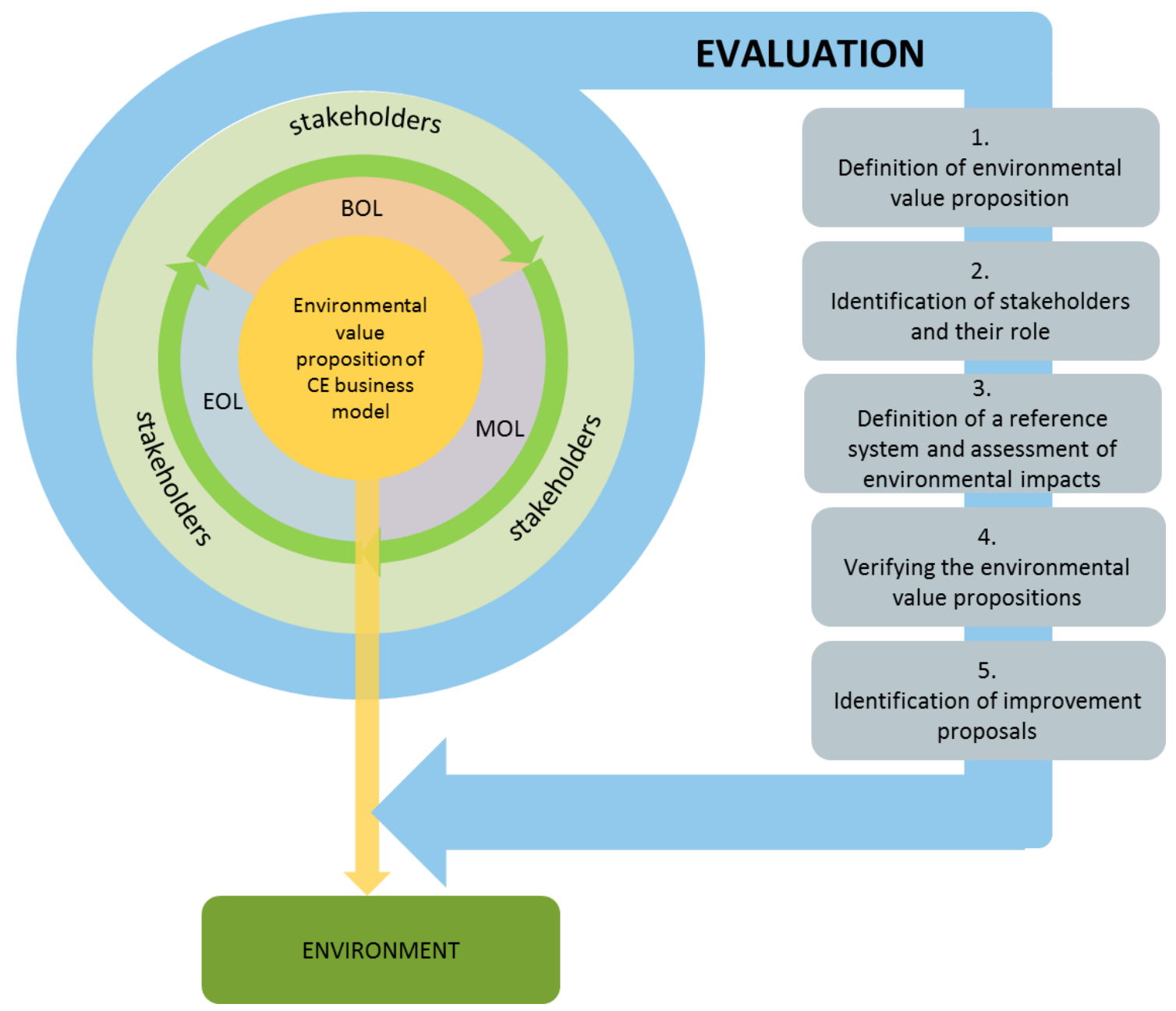

Figure 1. The environmental value proposition evaluation framework. $\mathrm{BOL}=$ beginning of life, $\mathrm{MOL}=\mathrm{middle}$ of life, $E O L=$ end of life.

\subsection{Environmental value proposition table (EVPT)}

The core of the evaluation framework is the environmental value proposition table (EVPT). The EVPT helps companies to understand what kind of effects their operation can have on the environment, and it helps to perceive environmental value as an absolute value. The environmental value propositions were developed based on the Ellen McArthur Foundation's CE principles (Ellen MacArthur Foundation et al., 2015), the CE characteristics 
identified by the European Environment Agency (EEA, 2016), and the CE business model categories of the ReSOLVE framework (Ellen MacArthur Foundation et al., 2015).

In the development process of the EVPT, it was assumed that the EEA's key characteristics of CE can be interpreted as environmental value propositions, which can be arranged under different CE business model categories (ReSOLVE actions). The aim of the EVPT is not to be comprehensive and cover all possible situations, but to provide a foundation for the consideration of environmental value propositions in CE business models.

The CE principles, environmental value propositions and CE business model categories of the ReSOLVE framework are summarised in Table 2. The EVPT shows how environmental value propositions can be arranged under the different CE business model categories (ReSOLVE actions). The last four propositions below the triple line are more like methods to achieve the value propositions. However, they are listed in the table because they are mentioned in the CE characteristics of the EEA (2016). The final value proposition above the triple line, namely Reclaiming, retaining or restoring the health of ecosystems, was added to the list as an outcome of our EVPT development process, because the ecosystem viewpoint was missing in the Regenerate category. 


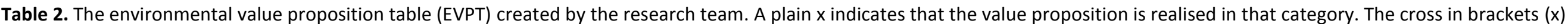

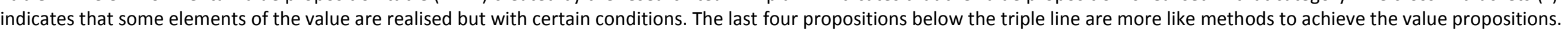

The last value proposition above the triple line is the outcome of our EVPT development process.

\begin{tabular}{|c|c|c|c|c|c|c|c|}
\hline \multirow[b]{2}{*}{ Circular economy principles ${ }^{1}$} & \multirow[b]{2}{*}{ Environmental value propositions ${ }^{2}$} & \multicolumn{6}{|c|}{ Circular economy business model categories $^{1}$} \\
\hline & & Regenerate & Share & Optimise & Loop & Virtualise & Exchange \\
\hline \multirow{6}{*}{$\begin{array}{c}\text { Principle 1: Preserve and } \\
\text { enhance natural capital by } \\
\text { controlling finite stocks and } \\
\text { balancing renewable resource } \\
\text { flows. }\end{array}$} & $\begin{array}{l}\text { Minimised and optimised exploitation of raw materials, while } \\
\text { delivering more value from fewer materials }\end{array}$ & & $x$ & $x$ & $x$ & $x$ & $(x)$ \\
\hline & Reduced import dependence on natural resources & & & & $(x)$ & & $(x)$ \\
\hline & Efficient use of all natural resources & & $x$ & $x$ & $x$ & $x$ & $(x)$ \\
\hline & Minimised overall energy and water use & & $\mathrm{x}$ & $x$ & & $(x)$ & $(x)$ \\
\hline & $\begin{array}{l}\text { Non-renewable resources replaced with renewable ones within } \\
\text { sustainable levels of supply }\end{array}$ & $x$ & & & & & \\
\hline & $\begin{array}{l}\text { Increased share of recyclable and recycled materials that can replace } \\
\text { the use of virgin materials }\end{array}$ & $(x)$ & & & $x$ & & $(x)$ \\
\hline \multirow{3}{*}{$\begin{array}{l}\text { Principle 2: Optimise resource } \\
\text { yields by circulating products, } \\
\text { components and materials at the } \\
\text { highest utility at all times in both } \\
\text { technical and biological cycles. }\end{array}$} & Closure of material loops & $x$ & & & $x$ & & \\
\hline & Sustainably sourced raw materials & $(x)$ & & & & & $(x)$ \\
\hline & $\begin{array}{l}\text { Reduced emissions throughout the full material cycle through the use } \\
\text { of less raw material and sustainable sourcing }\end{array}$ & $(x)$ & $x$ & $x$ & $(x)$ & $(x)$ & $(x)$ \\
\hline \multirow{6}{*}{$\begin{array}{l}\text { Principle 3: Foster system } \\
\text { effectiveness by revealing and } \\
\text { designing out negative } \\
\text { externalities. }\end{array}$} & Less pollution through clean material cycles & & & $x$ & $(\mathrm{x})$ & & $(\mathrm{x})$ \\
\hline & Build-up of waste minimised & & $x$ & $x$ & $\mathrm{x}$ & $\mathrm{x}$ & $(x)$ \\
\hline & Incineration and landfill limited to a minimum & & $x$ & & $x$ & $x$ & $(x)$ \\
\hline & Reclaim, retain and restore health of ecosystems & $x$ & & & & & $(x)$ \\
\hline & Dissipative losses of valuable resources minimised & & $(x)$ & $x$ & $x$ & $x$ & $(x)$ \\
\hline & Extended product lifetime keeping the value of products in use & & $x$ & $x$ & & & \\
\hline
\end{tabular}




\subsection{Step-by-step approach to evaluation}

The framework includes step-by-step stages for evaluating the environmental value propositions given by a specific CE business model. The content of the steps are described in more detail in Figure 2.

\begin{tabular}{|c|c|}
\hline \multicolumn{2}{|l|}{ 1. Definition of environmental value proposition } \\
\hline $\begin{array}{l}\text { To understand the system under study, the value chain/life cycles of } \\
\text { the product or services are gone through. }\end{array}$ & $\begin{array}{l}\text { The business model category and specific environmental value } \\
\text { propositions of a case company's business model are defined with } \\
\text { the help of EVPT. }\end{array}$ \\
\hline \multicolumn{2}{|l|}{ 2. Identification of stakeholders and their role } \\
\hline $\begin{array}{l}\text { The relevant stakeholders of the CE business model in the whole } \\
\text { value chain are defined. }\end{array}$ & $\begin{array}{l}\text { The stakeholders' roles and actions needed to promote the fulfilment } \\
\text { of environmental value proposition are identified. }\end{array}$ \\
\hline \multicolumn{2}{|c|}{ 3. Definition of reference system and assessment of environmental impacts } \\
\hline $\begin{array}{l}\text { The reference system is defined for the comparison of } \\
\text { environmental impacts. Data collection of the CE case. }\end{array}$ & $\begin{array}{l}\text { The comparison of a reference system with a CE business model } \\
\text { system and an assessment of environmental impacts, with } \\
\text { streamlined LCA, MFA, qualitative methods etc. }\end{array}$ \\
\hline \multicolumn{2}{|l|}{ 4. Verifying the environmental value propositions } \\
\hline $\begin{array}{l}\text { The realised environmental benefits related to different stakeholders } \\
\text { are identified based on the previous step and compared with the } \\
\text { environmental value proposition. }\end{array}$ & $\begin{array}{l}\text { Finally, the realisation of the environmental value propositions of a } \\
\text { CE business model is assessed. }\end{array}$ \\
\hline \multicolumn{2}{|l|}{ 5. Identification of improvement proposals } \\
\hline $\begin{array}{l}\text { Based on the previous step, possible improvement proposals for the } \\
\text { value chain of the business model to fulfill the value proposition are } \\
\text { identified. }\end{array}$ & $\begin{array}{l}\text { Identification of ways to prevent unintended consequences/rebound } \\
\text { effects. }\end{array}$ \\
\hline
\end{tabular}

Figure 2. Step-by-step approach of the evaluation framework.

The procedure requires close cooperation between the researchers and the case company. In addition, other experts can be consulted on demand. In principle, three first steps until defining the reference system, are executed during the interview with the company representatives, and rest of the steps after the interview by the researchers, with the help of company representatives and other experts if needed. However, the division of the steps between the steps before and after interview is not strict. More important is that researchers, executing the assessment, verifying and identification steps, get enough background information and data. Therefore, especially the first step is important to go 
through thoroughly and with the company representatives who know the operation of the company well enough.

\section{Methodology}

Considering that the aim of our study was to present the concept of environmental value proposition and to develop the framework for verifying the environmental value propositions of CE business models, we adopted a qualitative research approach. The developed framework consist elements from existing studies but was applied in the new context. Therefore we chose the case study research approach for testing the framework, because it is often useful in the early stages of a new research topic and can also be used for theory testing (Myers, 2013). In theory, one case is sufficient for building a logical argumentation of theoretical generalisation (Yin, 2013). However, replications increase the reliability of the findings and when replications differ slightly from each other, one or more relevant criteria may be changed to investigate whether the findings of the first case can be applied to slightly different situations (Hillebrand et al., 2001). In our study, we built up a table of environmental value propositions, which we assumed to cover main CE business model categories. Therefore, it was important to test the table with multiple cases in order to find out, if some substantial propositions were missing.

\section{Case selection and descriptions}

In this study, we used theoretical sampling (Eisenhardt, 1989). We chose to test our framework with three business model cases, which represent different circular economy (CE) business models and cover most of the ReSOLVE categories (see Tables 1 and 3). All the three case companies wanted to investigate and develop their operation from the CE perspective. Case 1 represents a CE product in Finland, while cases 2 and 3 represent two types of CE service models, established in Finland and the Netherlands (Table 3).

Table 3. Circular economy (CE) business model cases and their descriptions and defined CE business model categories according to the ReSOLVE framework (Ellen MacArthur Foundation et al., 2015)

\begin{tabular}{lll}
\hline Cases & Description & CE business model category \\
\hline Case 1. Wood stone by Destaclean & $\begin{array}{l}\text { Material recycling company } \\
\text { producing wood stone. }\end{array}$ & regenerate, optimise, loop
\end{tabular}


Case 2. Tool Renting Shed by Coreorient

Case 3. Pay-per-use washing machine by HOMIE
Self-service point for power tools and house cleaning equipment renting. Other services like shoemaker and bike service included.

Pay-per-use washing machine with free installation and maintenance. share, optimise, virtualise, (exchange)

share, optimise

The Finnish material recycling company Destaclean produces wood stone, which is a recycled composite product made of recycled construction waste wood, concrete and water. Wood stones are suitable for paving gardens and pathways, and they can withstand car traffic. (Destaclean, 2014).

A pilot of the company Coreorient, which ran from September to November 2016 called the Tool Renting Shed, is a 24/7 self-service point in Helsinki, Finland, where battery-powered tools and house cleaning equipment from the product range of a hardware shop can be rented from a smart container (Liiteri, 2016). The container is movable and can be easily relocated. The tools are rented and paid for on the internet and they can be collected from the container at any time. The container is easily accessible by public transport, or alternatively, home delivery can be ordered with the environmentally-friendly crowdsourced PiggyBaggy service (PiggyPaggy, 2016). Additionally, the Tool Renting Shed pilot offered other time-saving CE services, like a bike service and a shoe maker.

HOMIE is an innovative start-up, a spin-off of Delft University of Technology in the Netherlands, which aims to operate at the forefront of the circular economy by proposing, developing and testing new circular business models with consumers to reduce the need for "stuff" and ownership. The aim is to help customers reduce environmental impact in the home, by moving from "ownership" to "pay-per-use" through a service-driven business model, offering free installation and maintenance of a high-quality washing machine, with the cost of water and electricity included in a small fee charged per washing cycle. Washing machines are only the start: the aim is to target all appliances commonly found in the home. (HOMIE, 2016)

\section{Data collection}


The primary data was collected by interviews following the step-by-step approach (Figure 2). The interviews lasted approximately 1.5 hours, they were not recorded but detailed notes were taken. The interviews of Destaclean and Coreorient was done face-to-face and in writing with HOMIE. Two company representatives from Destaclean and one representative from Coreorient participated in the interview. All the four co-founders ${ }^{1}$ of HOMIE gave input to the interview, and questions and written answers were clarified via emails and phone call with one of the co-founders.

\section{Data analysis}

Analysis started by identifying the current business model and describing the life cycle stages and stakeholders, which were related to the system. The environmental value propositions of the business models and possible improvement proposals were recognised. Further, emerging findings were examined in order to verify the realisation of environmental value propositions.

\section{Results of the business model cases}

\subsection{Definition of environmental value proposition}

The implementation of the developed framework with the wood stone and Tool Renting Shed cases started by interviewing company representatives. Dialogues began with company presentations and by discussing and drawing the system boundaries of the business models. After sharing the common understanding of the case activities, it was time to explore environmental value propositions of the business models. First, the company representatives described the value propositions themselves, and then they were given the EVPT (Step 1 of the evaluation process). From the EVPT the representatives chose between four and six of the most important environmental value propositions related to their business models and put them in order of importance (Table 3).

\footnotetext{
${ }^{1}$ One of the writer of this article is also a co-founder of HOMIE.
} 
In the HOMIE case, one of the co-founders (and co-author) developed the first draft, which was sent to two other HOMIE co-founders for review. The written piece was reviewed for clarity by the other co-authors of this paper. This process led to a prioritisation about the initial intended value propositions (focused on user behaviour and access to longer lasting appliances) and ultimate outcomes (an integrated system for reuse, remanufacturing and recycling).

Table 3. Environmental value propositions in the order of importance defined by the cases. The pay-per-use washing machine case has three value propositions, which are ranked fourth in order of importance. Case representatives also defined additional value propositions apart from the EVPT, as presented below the double line.

Environmental value propositions by EVPT

\section{Cases}

$\begin{array}{ccl}\text { Wood stone } & \text { Tool Renting } & \text { Pay-per-use } \\ \text { Shed } & \text { washing } \\ & \text { machine }\end{array}$

\begin{tabular}{|c|c|c|c|}
\hline $\begin{array}{l}\text { Minimised and optimised exploitation of raw materials, } \\
\text { while delivering more value from fewer materials }\end{array}$ & 2 & 4 & 3 \\
\hline Reduced import dependence on natural resources & & 5 & \\
\hline Efficient use of all natural resources & & 1 & 2 \\
\hline Minimised overall energy and water use & & 2 & 1 \\
\hline \multicolumn{4}{|l|}{ Non-renewable resources replaced with renewable ones } \\
\hline \multicolumn{4}{|l|}{ within sustainable levels of supply } \\
\hline $\begin{array}{l}\text { Increased share of recyclable and recycled materials that } \\
\text { can replace the use of virgin materials }\end{array}$ & 1 & & 4 \\
\hline Closure of material loops & & & 4 \\
\hline \multicolumn{4}{|l|}{ Sustainably sourced raw materials } \\
\hline Reduced emissions throughout the full material cycle & & & 4 \\
\hline \multicolumn{4}{|l|}{ through the use of less raw material and sustainable } \\
\hline \multicolumn{4}{|l|}{ sourcing } \\
\hline \multicolumn{4}{|l|}{ Less pollution through clean material cycles } \\
\hline Build-up of waste minimised & & 3 & \\
\hline Incineration and landfill limited to a minimum & 3 & & \\
\hline
\end{tabular}


Case-specific environmental value propositions

Increasing the lifespan of wood fibre

Minimising the use of natural resources through tool

sharing

Long-lasting products

Supports travelling without a car

\subsection{Identification of stakeholders and their role}

Step 2 includes the definition of stakeholders related to the business model. The key stakeholders for all cases are customers, potential partners and the environment. The natural "Environment", analogous to the sustainable business model literature, also is a key stakeholder (Driscoll and Starik, 2004, Starik, 1995, Stubbs and Cocklin, 2008). However, first of all, customers are essential because without customers there is no viable business.

In addition to the above-mentioned, important stakeholders for the wood stone case are regional authorities, because they set the regulations (e.g. plan and decide on the locations for reception of wastes) for construction and demolition waste, which Destaclean uses as raw material for wood stone. Research institutes are also considered as important stakeholders, because they can assist in developing substitutes for the cement, one of the raw materials of wood stone, for example.

For the Tool Renting Shed case, many important stakeholders, who enabled the pilot of tool sharing service, were identified. As an example, the tool retailers sponsored the tools, web- 
service experts created the renting platform on the internet, and the City of Helsinki provided the space for the container.

For HOMIE, the university is a key stakeholder as they share close ties, being a spin-off and one of its co-founders being TU Delft faculty. As well as optimising the customer experience, HOMIE seeks to reduce the environmental impact of washing machines (and in future, other appliances) through its pay-per-use service model. Finally, future partners need to be considered and the company needs to consider whether and how to work with existing appliance makers. However, in this respect, similar environmental goals are needed focused on long lasting appliances and stimulating sustainable behaviour.

\subsection{Definition of a reference system and assessment of environmental impact}

In order to verify the environmental value propositions of business model cases, the reference systems must be defined (such as in ISO 14040:2006). As CE business models may represent new systems, defining the reference can be difficult. However, often CE business models attempt to seek options for current technologies or create alternative practices for existing linear systems. The reference systems of the cases were defined by asking: what is the product system/service that the business model case could substitute or replace in theory?

A concrete stone was chosen for the reference system for the wood stone, because the end use of wood stone is comparable to concrete stone paving. The environmental value propositions selected were all somehow related to the end products. Therefore, the choice of concrete stone as a reference system was reasonable.

The Tool Renting Shed business model is a service model and therefore the choice of the reference system was more multidimensional than in the wood stone case, as it included other services than just tool rental. The following reference system was defined by concentrating on the core of the business model: "Consumer travelling by car to the hardware shop to buy a low-quality tool or house cleaning equipment". 
The reference system of pay-per-use washing machines is the current usage of washing machines. While averages of washing behaviour exist based on surveys (e.g. through the work by the International Association for Soaps, Detergents and Maintenance Products (A.I.S.E., 2014) the actual usage of washing machines remains under-investigated. HOMIE therefore asks customers how often they think they do their washing before they start using the washing machine, and then use the customers as their own benchmark (i.e. comparing usage against predicted usage, and investigating to what extent the pay-per-use business model contributes to sustainable usage).

\subsection{Verifying the environmental value propositions}

In the verification process, the value chains were divided into the beginning of life (BOL), middle of life (MOL) and end of life (EOL), and named after different life cycle phases: raw material acquisition and processing (BOL), transportation (BOL, $\mathrm{MOL}, \mathrm{EOL})$, use phase (MOL) as well as end-of-life (EOL). The realisation of each value proposition in each life cycle phase was assessed based on the interviews of the company representatives and expertise of the researchers (Table 4). The cell was left empty if the realisation of value proposition was not distinguished in the specific life cycle phase. The explanations in the table describe the operation or phase, where the environmental value proposition is realised and how it is realised without giving any quantitative measures.

Table 4. Realisation of environmental value propositions assessed in the life cycle phases of raw material acquisition and processing, transportation, use phase and end-of-life divided into the phases of beginning of life (BOL), middle of life (MOL) and end of life (EOL)

\begin{tabular}{|c|c|c|c|}
\hline $\begin{array}{c}\text { Environmental value } \\
\text { proposition }\end{array}$ & $\begin{array}{l}\text { Raw material } \\
\text { acquisition and } \\
\text { processing } \\
\text { (BOL) }\end{array}$ & $\begin{array}{l}\text { Transportation } \\
\text { (BOL, MOL. EOL) }\end{array}$ & $\begin{array}{l}\text { End-Of-Life } \\
\text { (EOL) }\end{array}$ \\
\hline \multicolumn{4}{|c|}{ Wood stone - reference system: concrete stone. } \\
\hline $\begin{array}{l}\text { 1. Increased share of } \\
\text { recyclable and } \\
\text { recycled materials } \\
\text { that can replace the } \\
\text { use of virgin } \\
\text { materials }\end{array}$ & $\begin{array}{l}\text { substituting sand } \\
\text { material with recycled } \\
\text { wood fibre }\end{array}$ & & $\begin{array}{l}\text { value propositions } \\
\text { 1-4: potential } \\
\text { recycling } \\
\text { options/possibilities } \\
\text { but not existing } \\
\text { recycling system }\end{array}$ \\
\hline
\end{tabular}




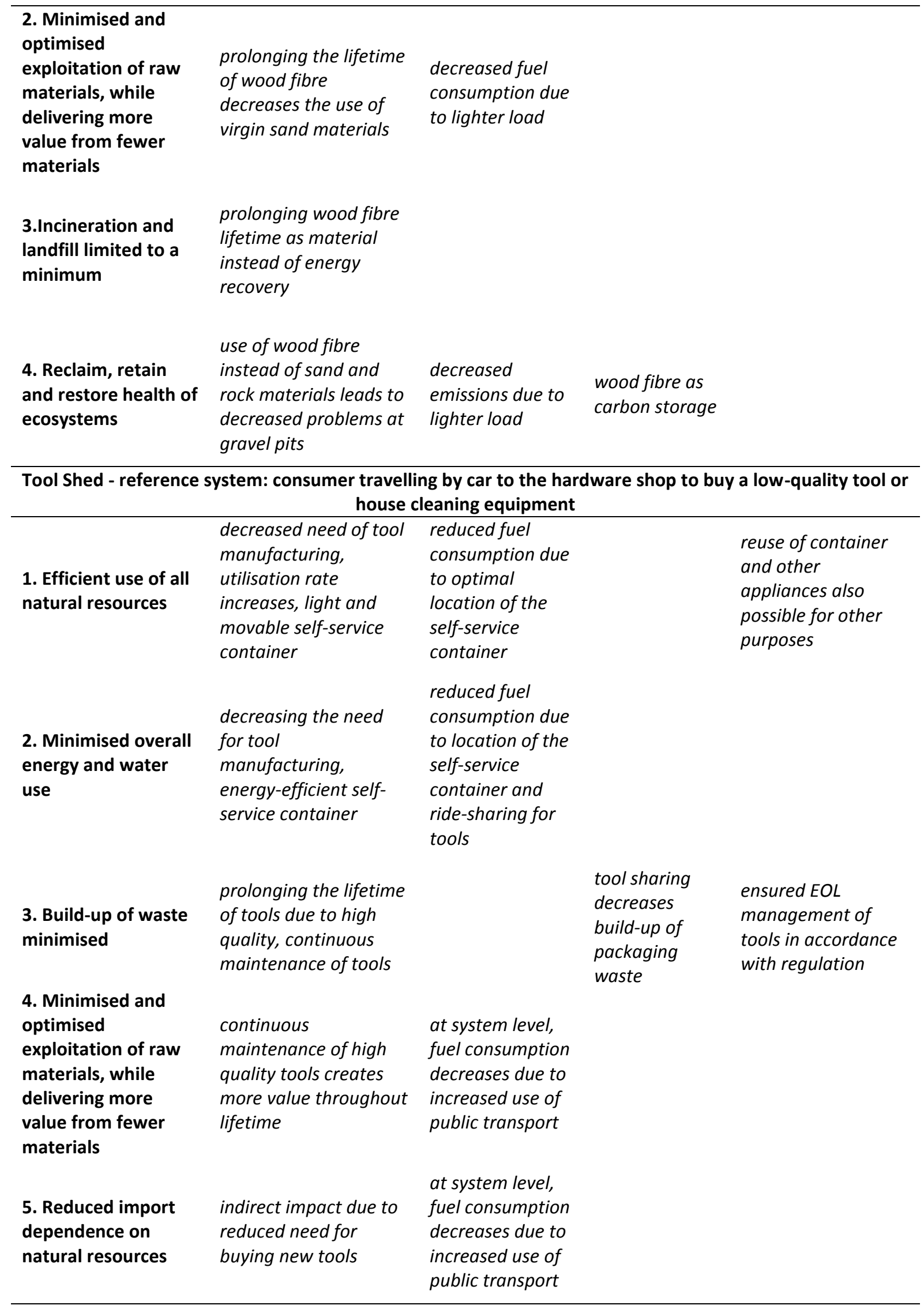




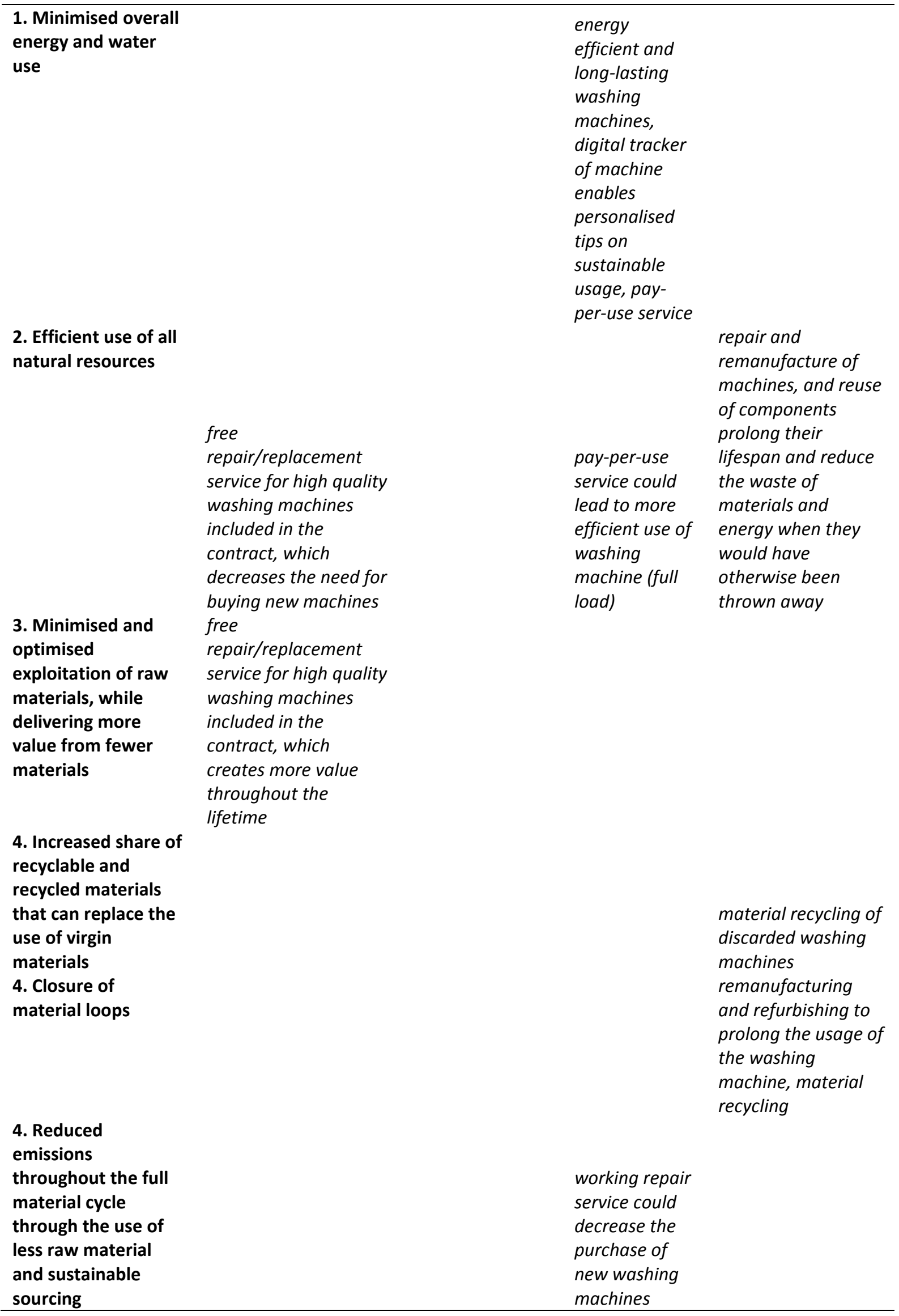


The verification phase showed that all the intended environmental value propositions could be identified, which means that the analysed CE business model cases potentially create environmental value. However, not all the propositions were directly achieved by the case companies, but through the stakeholders. For example, some of the value propositions could not be realised up until the use phase, which means that the choices by users of the products or services play a big role. The environmental value in these cases can obviously not be created if the product or service does not have an end user.

\subsection{Identification of improvement proposals}

Few improvement proposals for the wood stone operations, which are more related to the raw materials and processing phase than the use phase, could be found by the researchers and company representatives. Because cement production is a very energy-intensive process, causing a lot of emissions (Vieira et al., 2016), a substitute for cement could lower the total environmental impacts of wood stone. Available material banks, e.g. Finnish soil market (Maapörssi, 2017) could be utilised to find recycled material (e.g. sand) for the raw materials. The process energy and transportation fuels could be changed to sustainably produced renewable energy to reduce the environmental impact.

In the Tool Renting Shed case, the tools could be upgraded to even higher quality and to include other services to the tool sharing concept. In addition, a more central location for the self-service container (at the railway station or some other public transport node) would reach a wider population more easily and thus raise the utilisation rate of the tools. Also, further development of the smart container could create extension possibilities for the business model. For example, the user interface needs some development, as it was a little clumsy during the pilot phase. Therefore, the collaboration with new experts in information technology could be useful. One important part of this kind of new service is communication and marketing to reach more people, where there is still some work to do. The service entity of the Tool Shed also provided some other small services, such as a shoemaker and a bike service in addition to tool sharing, and other services could be combined with the service in the future, thus requiring new stakeholders. 
In the pay-per-use appliances case, HOMIE could improve the customer service as well as environmental proposition at the same time. By developing an improved user interface (e.g. an app) and with a more mature business (including a remanufacturing, reuse and repair facility) they could better serve the customer as well as the environment. As it is a spin-off from Delft University of Technology, HOMIE could use its position and target students and link in with the "company's heritage". Focusing on low-income groups more generally could make quality appliances that last long available to a wider customer base. By stimulating better use of appliances (e.g. use only when needed and in lower environmental impact settings) these customers could save money and reduce their environmental footprint. To reach the goals more quickly, HOMIE could identify new strong partners (e.g. appliance manufacturers).

\section{Discussion}

\subsection{Step-by-step approach}

The evaluation framework gives companies and researchers a consistent approach for the evaluation of the realisation of environmental value propositions of CE business models. The framework consists elements from existing approaches (e.g. LCA), but our framework can easily be applied for business models at the different stages; from start-ups to companies having several years of business experience. In this study, the aim of the case study phase was to test the evaluation framework in practice and identify any possible development needs. Experiences from the interviews indicated that the step-by-step approach is a logical and practical way to gather the background information and to define the environmental value propositions of the business model.

\subsection{Environmental value proposition table}

A key component of the evaluation framework was the environmental value proposition table (EVPT, Table 2). The strength of the EVPT is that it helps companies to perceive environmental value as an absolute value. In addition, it provides companies a tool to consider their operation from the environmental perspective and guides them to determine their own environmental value propositions according to the principles of CE and priorities 
actions. Many of the CE business models represent elements from various business model categories, thus bringing out the multidimensionality of CE. For example, the Tool Renting Shed represents the category "share" by maximising the utilisation of products by sharing them among users but at the same time virtualise the service through online renting. Additionally, the systemic approach helps to understand that a company's own activities do not necessarily directly, but indirectly fulfil the value creation through the stakeholders.

\subsection{Reference system}

The practical experience showed that it is important to understand the core of the business model to be able to define the suitable reference system (describing the current situation) for the evaluation. The reference system is needed to assess the environmental impacts gained from implementing the value propositions. However, CE business models often represent new solutions and systems, and so defining the reference might be difficult. In addition, defining appropriate boundaries for studied systems and finding the data may be a problem when assessing systems that do not exist yet. Additionally, an assessment of the consequences of scaling up production may be challenging, and demonstrating the systematic effects in the future may even be impossible. Therefore, assessment methods have to be chosen carefully and it should be ensured that results truly reflect defined value propositions. For instance, LCA (according to ISO 14040:2006) as being developed for products and services, not for business models, is not always suitable and it is often too time- or resource-demanding for companies, but a streamlined LCA is feasible in many cases (Bocken et al., 2016a). This means that other approaches are needed. For example, the assessment can be conducted by defining suitable quantitative or qualitative indicators, which set the criteria for value realisation. In some cases, as shown in this study, qualitative methods may be an alternative where a numeric calculation is impractical.

\subsection{Limitations of the study}

The present EVPT is not meant to be final and comprehensive - it is there to be developed over time as the CE business models develop further and their multidimensional perspectives are understood more thoroughly. In the future, the EVPT could be used as a starting point and for assistance when developing more case-specific value propositions. 
In the case studies, the final conclusion about the realisation of single environmental value proposition at the system level was not scientifically verified. However, the evaluation showed that estimating the realisation of the propositions in different life cycle phases is possible. The evaluation also pointed out that even if the reference system is well defined, performing a qualitative assessment is easier than quantitative measures. The additional value of the quantitative calculation is also questionable if the assessed environmental value proposition does not give any clear measurable claim such as decreased emissions. If the evaluation process is used to assist in process development, for example, then calculated quantitative results could be useful and more detailed process data would be needed. In our study the EVPT included quite general value propositions and therefore the qualitative assessment was reasonable. In this work, the stakeholders that are important for the business models were identified and their roles and actions in promoting the environmental value propositions were discussed. Result showed, that all the analysed cases could create environmental value also through stakeholders. Future work could add the economic perspective to the analysis to see, how the environmental and economic value creation relates to each other in different life cycle phases.

\section{Conclusion}

In this work, the literature on the circular economy principles and characteristics were considered, and as an outcome the framework for evaluation of the verification of the environmental value propositions of circular economy business models were outlined. The framework consists of the environmental value propositions table (EVPT) and the step-by step approach to the evaluation process. The EVPT brings out that environmental values can be considered as absolute values of the business models, by presenting concrete value propositions of CE business models under the different CE business model categories. The step-by-step approach, instead provides instructions for the execution of the evaluation process in practice.

The verification of environmental value propositions and possible positive influence on the environment requires a systematic approach, taking into account all stakeholders and the entire life cycle of a product or service. The outlined framework provides a better 
understanding of circular economy principles, combining them with the environmental value proposition. Overlapping characteristics of different circular economy business model categories emerged during the utilisation of the framework. Also, some challenges were faced when applying the framework in different cases representing different CE business model categories. However, the biggest challenges were related to the estimation of environmental benefits gained from the environmental value propositions at the system level. In the future, intensive scientific work should concentrate on developing environmental assessment methods specifically for companies developing new CE business models.

With the framework outlined here, companies can plan and design new CE business models or they can verify intended environmental benefits. The framework is flexible and enables modifications for various companies, but it still requires further development. Future research should concentrate on to develop framework more case specific and also to provide more quantitative measures about the environmental benefits gained.

\section{Acknowledgements}

This work is part of the Capitalising on Invisible Value - User-driven Business Models in the Emerging Circular Economy (AARRE) project. We would like to thank Tekes (the Finnish Funding Agency for Innovation) for financing, and the case companies for their participation. 


\section{References}

A.I.S.E., 2014. International Association for Soaps, Detergents and Maintenance Products. https://www.aise.eu/. Accessed Jan 12017.

Antikainen, M., Valkokari, K., 2016. A Framework for Sustainable Circular Business Model Innovation. Technology Innovation Management Review 6, 5-12.

Bakker, C., Wang, F., Huisman, J., Den Hollander, M., 2014. Products that go round: exploring product life extension through design. Journal of Cleaner Production 69, 10-16.

Bocken, N.M.P., Miller, K., Evans, S., 2016a. Assessing the environmental impact of new Circular business models. Conference "New Business Models" - Exploring a changing view on organizing value creation - Toulouse, France, 16-17 June 2016.

Bocken, N.M.P., de Pauw, I., Bakker, C., van der Grinten, B., 2016b. Product design and business model strategies for a circular economy. Journal of Industrial and Production Engineering 33, 308-320.

Bocken, N., Short, S., Rana, P., Evans, S., 2013. A value mapping tool for sustainable business modelling. Corporate Governance: The international journal of business in society $13,482-$ 497.

Boons, F., Lüdeke-Freund, F., 2013. Business models for sustainable innovation: state-of-theart and steps towards a research agenda. Journal of Cleaner Production, 9-19

Destaclean, 2014. Destamatic's wood stones are the next generation of recycled products. http://www.destamatic.fi/files/DestaClean woodStones info Oct2014.pdf. Accessed Jun 14 2017.

Driscoll, C., Starik, M., 2004. The Primordial Stakeholder: Advancing the Conceptual Consideration of Stakeholder Status for the Natural Environment. Journal of Business Ethics 49, 55-73. 
EEA, 2016. Circular economy in Europe. Developing the knowledge base. EEA Report No $2 / 2016$

Eisenhardt, K.M., 1989. Building Theories from Case Study Research. The Academy of Management Review 14, 532-550.

Ellen MacArthur Foundation, McKinsey Center for Business and Environment, SUN, 2015. Growth Within: A Circular Economy Vision for a Competitive Europe

European Commission, 2015. Communication from the commission to the European parliament, the council, the European economic and social committee and the committee of the regions. Closing the loop - An EU action plan for the Circular Economy. COM(2015) 614 final

Geissdoerfer, M., Savaget, P., Bocken, N.M.P., Hultink, E.J., 2017. The Circular Economy - A new sustainability paradigm?. Journal of Cleaner Production 143, 757-768.

Ghisellini, P., Cialani, C., Ulgiati, S., 2016. A review on circular economy: the expected transition to a balanced interplay of environmental and economic systems. Journal of Cleaner Production 114, 11-32.

Hillebrand, B., Kok, R., Biemans, W.G., 2001. Theory-testing using case studies - A comment on Johnston, Leach, and Liu. Industrial Marketing Management 30, 651-657.

HOMIE, 2016. HOMIE pay-per-use appliances. http://www.homiepayperuse.com/. Accessed Jun 142017.

Joyce, A., Paquin, R.L., 2016. The triple layered business model canvas: A tool to design more sustainable business models. Journal of Cleaner Production 135, 1474-1486.

Kraaijenhagen, C., V., van Oppen, C., Bocken, N., 2016. Circular Business: Collaborate and Circulate. Circular Collaboration. Available at: www.circularcollaboration.com.

Lewandowski, M., 2016. Designing the Business Models for Circular Economy-Towards the Conceptual Framework. Sustainability 8, 43. 
Liiteri, 2016. 24h tool rental and self-service point at Teurastamo. http://liiteri.net/en/.

Lindahl, M., Sundin, E., Sakao, T., 2014. Environmental and economic benefits of Integrated Product Service Offerings quantified with real business cases. Journal of Cleaner Production 64, 288-296.

Maapörssi, 2017. Soil market. http://www.maaporssi.fi/. Accessed Jun 142017.

Mont, O.K., 2002. Clarifying the concept of product-service system. Journal of Cleaner Production 10, 237-245.

Mont, O., 2004. Product-service systems: Panacea or myth? IIIEE, Lund University, Lund Myers, M.D., 2013. Qualitative research in business \& management, 2nd edition ed. SAGE, Los Angeles

Osterwalder, A., Pigneur, Y., 2010. Business Model Generation - A Handbook for Visionaries, Game Changers, and Challengers. Wiley

Patala, S., Jalkala, A., Keränen, J., Väisänen, S., Tuominen, V., Soukka, R., 2016. Sustainable value propositions: Framework and implications for technology suppliers. Industrial Marketing Management 59, 144-156.

PiggyPaggy, 2016. Ride-sharing for goods. http://piggybaggy.com/en/. Accessed Jun 142017.

Schaltegger, S., Hansen, E.G., Lüdeke-Freund, F., 2016. Business Models for Sustainability. Organization \& Environment 29, 3-10.

Stahel, W.R., 2010. The performance economy, 2. ed. ed. Palgrave Macmillan UK

Starik, M., 1995. Should trees have managerial standing? Toward stakeholder status for nonhuman nature. Journal of Business Ethics 14, 207-217.

Stubbs, W., Cocklin, C., 2008. Conceptualizing a "Sustainability Business Model". Organization \& Environment 21, 103-127. 
SUN, Ellen, M.F., McKinsey Center for Business, and Environment, 2015. Growth Within: a circular economy vision for a competitive Europe

ten Wolde, A., 2016. Circular Business Models. The Sustainable Innovation 2016 Conference 'Circular Economy' Innovation \& Design in Epsom, UK, 8 November 2016

Tukker, A., 2015. Product services for a resource-efficient and circular economy - a review. J. Clean. Prod. 97, 76-91.

Tukker, A., 2004. Eight types of product-service system: eight ways to sustainability? Experiences from SusProNet. Business Strategy and the Environment 13, 246-260.

Tyl, B., Vallet, F., Bocken, N.M.P., Real, M., 2015. The integration of a stakeholder perspective into the front end of eco-innovation: a practical approach. Journal of Cleaner Production 108, 543-557.

Upward, A., Jones, P., 2016. An Ontology for Strongly Sustainable Business Models. Organization \& Environment 29, 97-123.

Vieira, D.R., Calmon, J.L., Coelho, F.Z., 2016. Life cycle assessment (LCA) applied to the manufacturing of common and ecological concrete: A review. Construction and Building Materials 124, 656-666.

Yang, M., Vladimirova, D., Rana, P., Evans, S., 2014. Sustainable value analysis tool for value creation. Asian journal of management science and applications 1, 312-332.

Yin, R.K., 2013. Case Study Research Design and Methods, 5th edition ed. SAGE Publications, Thousand Oaks, CA, USA. 